Scientific Journal of October 6 University

ISSN (Print): 2314-8640

ISSN (Electronic): 2356-8119

Published by October 6 University @ All Rights Reserved

Available online at: http: sjou.journals.ekb.eg

Original Article
Citation: Shawky, (2018). Comparison of Biochemical effects of glibenclamide and some trace elements on experimental diabetic rats . Sci. J. of Oct. 6 Univ. 4(2), 1-7.

Copyright: (๑) 2018 Shawky S. This is an open-access article distributed under the terms of the Creative Commons Attribution License, which permits unrestricted use, distribution, and reproduction in any medium, provided the original author and source are credited.

\title{
Comparison of Biochemical effects of glibenclamide and some trace elements on experimental diabetic rats
}

\author{
Suzan Shawky ${ }^{1}$, Samy A. Abdel-Aziz ${ }^{2}$, Hassan A. Amer ${ }^{2}$, Ismail I. Hegazy ${ }^{1}$ and ${ }^{*}$ Mohammed A. \\ Hussein ${ }^{1}$
}

${ }^{1}$ Department of Biochemistry, Faculty of Applied Medical Sciences, October 6 University, Egypt

${ }^{2}$ Department of Biochemistry and Nutrition, Faculty of Veterinary Medicine, Cairo University, Egypt

Received: 10-03-2018/ Revised: 20-04-2018 / Accepted: 10-05-2018

\begin{abstract}
The present work was done to elucidate the possible protective and antidiabetic effect of chromium chloride (Cr) $(500 \mathrm{mg} / \mathrm{k.g}$.$) , sodium selenite (\mathrm{Se})(1.5 \mathrm{mg} / \mathrm{k.g}$.) and Zinc sulphate $(\mathrm{Zn})(54 \mathrm{mg} / \mathrm{k} . \mathrm{g}$.) supplementation in streptozotocin induced diabetic rats. Oral administration of both $\mathrm{Cr}^{+3}$ and $\mathrm{Zn}^{+2}$ as well as intraperitoneal injection of $\mathrm{Se}^{-2}$ at concentrations of $500,1.5$ and $54 \mathrm{mg} / \mathrm{kg}$ b.w. daily, respectively for 60 days showed a significant decrease in fasting blood. The treatment also resulted in a significant increase in plasma C-peptide and trace elements $\mathrm{Cr}^{+3}$ and $\mathrm{Zn}^{+2}$ and $\mathrm{Se}^{-2}$. The trace elements exerted rapid protective effects against lipid peroxidation by scavenging of free radicals by reducing the risk of diabetic complications.
\end{abstract}

Key Words: Glucose, diabetic rats, $\mathrm{Cr}^{+3}$ and $\mathrm{Zn}^{+2}$ and $\mathrm{Se}^{-2}$, C-peptide.

\section{Introduction}

Trace elements have been identified for long time as potential candidates for improving metabolic disorders like pre diabetes [insulin resistance, obesity, metabolic syndrome] or diabetes (Devirgiliis, et al., 2007). In parallel with increasing comprehension of cellular and biochemical mechanisms leading aggravatingthese metabolic disorders, identifying the cellular targets and sites of action of trace elements has reactivated interest in their therapeutic potential (Rungby., 2010). Activation of insulin receptor signalling (chromium), antioxidant properties (selenium, zinc) thus appeared promising in view of the key importance of these processes in glucose homeostasis and insulin sensitivity. Insulin receptor/postreceptor signalling defects are considered to underlie glycemic dysregulation and insulin resistance (Abdul-Ghani and defronzo ., 2010).

Chromium is an essential element involved in the regulation of blood glucose levels within the body (Guerrero and Rodríguez, 2005). It is believed to interact with the low-molecular weight chromium
(LMWCr) binding substance to amplify the action of insulin. Today, the use of chromium as a dietary supplement for the treatment of diabetes mellitus type 2 (Cefalu and $\mathrm{Hu}, 2004$ ).

Chromium acts as a potential regulator of glucose metabolism. The experimenters subjected the rats to a chromium deficient diet, and witnessed an inability of the organisms to respond effectively to increased levels of glucose within the blood (Lipko,et al., 2002). They then included "acidhydrolyzed porcine kidney and Brewer's yeast" in the diet of these rats, and found that the rats were now able to effectively metabolize glucose (Lewicki et al., 2005). Both the porcine kidney and Brewer's yeast were rich in chromium, and so it was from these findings that began the study of chromium as a regulator of blood glucose (Balk,et al.,2007).

Experimental evidence from animal models suggests that supplementation with low doses of the antioxidant selenium may exert beneficial effects on glucose metabolism, possibly through many insulin-like actions, and may delay

*Corresponding Author Address: Prof. Mohammed Abdalla Hussein: Department of Biochemistry, Faculty of Applied Medical Sciences, October 6 University, Egypt. E-mail: Prof.husseinma@ o6u.edu.eg 
complications of diabetes. Potential (Satyanarayana, et al ., 2004 and 2006).

Some studies in patients with diabetes suggest that selenium supplementation may help to prevent vascular complications and that diabetic patients may be deficient in selenium relative to healthy persons (Faure, et al., 2004). Animal studies suggest that dietary selenium from inorganic or organic sources was toxic at concentrations exceeding $5 \mathrm{ppm}(63.3 \mathrm{~mol})$, inorganic forms are used sodium selenite and/or sodium selenate mainly as additives of microelement fertilizers applied on leaves or directly to the soil. In organisms selenium is mostly present in the organic form of seleno-methionine and/or seleno-cysteine. (Navarro and Cabrera., 2008). Abnormal zinc and lipid plasma levels occur more frequently in metabolically uncontrolled diabetic patients. Yet, zinc sulfate supplementation may be a therapeutical resource to recover some functioning and improve life span the effect of zinc sulfate on glucose and lipid profile of type 2 diabetes mellitus patients (Partida-Hernandez et al., 2006). Diabetic patients have tendency to use complementary and alternative medicine beside routine therapies. Zinc is one of the minerals used by diabetic patients, (Anderson et al. 2001a) study on 110 patients type 2 diabetes mellitus with $\mathrm{HbA} 1 \mathrm{C}>7.5 \%$ revealed that more than $30 \%$ of the patients may have been zinc deficient after 6 weeks zinc sulfate treatment in FBS, 2hpp, HbA1C, HDL, BMI and diastolic blood pressure, (Anderson, et al., 2001b).

Preventing and treating essential trace elements for life as Zinc and iron that are two essential trace elements for life, playing a central role in many metabolic processes. More than 300 zinc metalloenzymes occur in all six categories of enzyme systems (Salgueiro et al., 2000; Jansen et al., 2009). Proteins can form domains able to bind tetrahedral zinc atoms by coordination with histidine and cysteine to form folded structures that have become known as zinc fingers. These biologically active molecules have important roles in gene expression (Saper and Rash., 2009).

Zinc ( $\mathrm{Zn})$ is an essential micronutrient which has an important role in insulin metabolism and acts as an efficient antioxidant (Maret and Sandstead .2006 and Prasad.,2008).

In streptozotocin (STZ)-treated diabetic rats, renal oxidative stress and kidney damage are increased by a dietary deficiency of the essential trace element selenium In contrast, selenium supplementation to rats or humans with diabetes reduces renal injury (Reddi and Bollineni , 2001). The present investigation was undertaken to assess the effect of hyperglycemia on the levels trace elements (Cr, Se and Zn) in streptozotocin (STZ) induced diabetic rats.

\section{Materials and Methods}

Materials

Chromium chloride, sodium selenite, Zinc sulphate, glibenclamide and streptozotocin were purchased from Sigma Aldrich (St. Louis, MO), USA.

\section{Animals}

A 225 Male albino rats (120-150 g) were obtained from animal house of Cancer Epidemiology, National Cancer Institute, Cairo University. Rats were fed on a standard diet and free access to tap water. They were kept for one week to be acclimatized to the environmental conditions.

\section{Experimental Design}

A 225 male albino rats were divided into 2 main groups the $1^{\text {st }}$ group included the normal healthy rats comprised of 100 rats while the $2^{\text {nd }}$ group was experimentally induced diabetic group and comprised of 125 rats (twenty five rats in each group).

The $\mathbf{1}^{\text {st }}$ group included the normal healthy rats were divided into 4 subgroups as follows:

Group 1: Given saline served as negative control. Group 2: Normal healthy control rats; orally administered with $\mathrm{Cr}(500 \mathrm{mg} / \mathrm{kg} \mathrm{BW})$ for 60 days (Zhongli, 2010).

Group 3: Normal healthy control rats; i.p injected with Se (1.5 mg/kg b.w.) as for 60 days (Zhongli, 2010).

Group 4: Normal healthy control rats; orally administered with Zn (54 mg zinc/kg. b.w.) for 60 days. daily (Zine et al,. 2007).

The $2^{\text {nd }}$ group was experimentally induced diabetic group and comprised of 125 rats.

Diabetic group was experimentally induced by injection with streptozotocin (STZ) i.p. in dose of $(65 \mathrm{mg} / \mathrm{kg} \mathrm{b}$. wt). STZ was dissolved in $0.01 \mathrm{M}$ citrate buffer $(\mathrm{pH}=4.6)$ immediately before use (Liu et al. 2008). After injection, animals had free access to food and water and were given 5\% glucose solution to drink overnight to encounter hyperglycemic shock. Animals were checked daily for the presence of glycosuria. Fasting blood samples were obtained after 7 days of STZ injection to ensure the induction of Hyperglycemic fasting blood sugar was determined (>300 mg/dl).

Diabetic rats were classified into 5 groups (25 rats for each group) as follows:

Groups 5: Considered as a positive control for diabetic rats.

Group 6: diabetic rats orally administered with the anti-diabetic drug glibenclamide $(5 \mathrm{mg} / \mathrm{kg}$ body weight daily for to month).

Group7: Diabetic rats; orally administered with $\mathrm{Cr}$ $(500 \mathrm{mg} / \mathrm{kg} \mathrm{BW})$ for 60 days.

Group 8: Diabetic animals; i.p. injected with $\mathrm{Se}$ ( $1.5 \mathrm{mg} / \mathrm{kg} \mathrm{b.w)} \mathrm{for} 60$ days . 
Group 9: Diabetic animals; orally administered with Zn (54 mg zinc/ mg/kg b.w. daily for 60 days

- Changes of body weight (gm) of rats in different groups were measured at $4^{\text {th }}$ and $8^{\text {th }}$ week.

\section{- Sample Preparations}

Blood samples were collected twice at the fourth week of experiment and at the end of experiment .heart tissue and liver were obtained after 60 days of administration. Blood samples were divided into 2 portions:-

$1^{\text {st }}$ portion containing blood samples left 10 minutes to clot and centrifuged at $3000 \mathrm{rpm}$ for serum separation, to used for determination of trace elements. $2^{\text {nd }}$ portion containing sodium citrate as anticoagulante for plasma separation to assayed blood glucose level according to the method of Trinder (1969) and plasma C-peptide according to the method of Bonger, and Garcia-Webb, (1984).

\section{Results}

Table 1 shows the body weight of control and experimental groups of rats. A significant decrease in body weight was observed in streptozotocin induced diabetic rats (Group II) when compared to the control group of rats (Group I) $(\mathrm{P} \leq 0.05)$. Trace elements $\left(\mathrm{Se}^{+2}\right.$ than $\mathrm{Cr}^{+2}$ and $\left.\mathrm{Zn}^{+2}\right)$ and glibenclamide administered rats (Groups III and VII-VIIII) showed progressive increase in body weight $(\mathrm{P} \leq 0.05)$.

Tables 2 and 3 shows the fasting plasma glucose and C-peptide levels in control and experimental groups of rats. There was a significant increase in plasma glucose and significant decrease in Cpeptide levels of diabetic control group compared with normal control rats $(\mathrm{P} \leq 0.05)$. Administration of trace elements $\left(\mathrm{Se}^{+2}\right.$ than $\mathrm{Cr}^{+2}$ and $\mathrm{Zn}^{+2}$ ) and glibenclamide tends to bring down the blood glucose and increase significantly of plasma Cpeptide levels compared with untreated diabetic rats $(\mathrm{P} \leq 0.05)$.

Table (4) shows the effect of trace elements $\left(\mathrm{Se}^{+2}\right.$ than $\mathrm{Cr}^{+2}$ and $\mathrm{Zn}^{+2}$ ) and glibenclamide on lipid profile. In STZ-induced diabetic rats, TC, TG and LDL-C levels were increased and HDL-C level was decreased significantly $(\mathrm{P}<0.05)$ compared with normal control rats. In diabetic rats, administration of trace elements $\left(\mathrm{Se}^{+2}\right.$ than $\mathrm{Cr}^{+2}$ and $\mathrm{Zn}^{+2}$ ) and glibenclamide showed significant reduction $(\mathrm{P}<0.05)$ of TC, TG and LDL-C levels compared with diabetic control rats. Also, a significant increase $(\mathrm{P}<0.05)$ level of HDL-C was observed in diabetic rats treated with both trace elements and glibenclamide compared with diabetic control rats.

\section{Discussion}

STZ induced diabetes is characterized by severe loss in body weight (Al-Shamaony et al., 1994) and this was also seen in the present study trace elements $\left(\mathrm{Se}^{+2}\right.$ than $\mathrm{Cr}^{+2}$ and $\left.\mathrm{Zn}^{+2}\right)$ and glibenclamide administration controlled this loss in body weight. However, it did not normalize the body weight completely as it remained lesser than normal control rats. The decrease in body weight observed in diabetic rats might be the result of protein wasting due to unavailability of carbohydrate for utilization as an energy source (Chen and Ianuzzo, 1982).

Chromium supplement increases protein synthesis. Thus, it is beneficial in building muscles. Moreover, Chromium supplementation has at best modest effects on body weight or composition in individuals with diabetes (Hallmark et al., 1996).

Mendez et al .,(2005) reported that non-enzymatic glycation of albumin was the potential to alter its biological structure and function. It is mainly due to the formation of a Schiff base between aminogroup of lysine (and sometimes arginine) residues and excess glucose molecules in blood to form glycoalbumin. Hypoalbuminemia is one of the factors responsible for the onset of ascites related to liver fibrosis (Horie et al., 1998).

The present results reveal the treatment of diabetic rats with trace elements $\left(\mathrm{Se}^{+2}, \mathrm{Cr}^{+2}\right.$ and $\left.\mathrm{Zn}^{+2}\right)$ or glibenclamide strengthens the endogenous antioxidant defenses from ROS and restores the optimal balance by neutralizing the reactive species. They are gaining a great importance by virtue of their critical role in disease prevention. Many studies have addressed the importance of antioxidants for the control of the abnormalities in diabetic tissue (Kowluru et al., 2001 and Obrosova et al., 2001).

Trace elements; especially $\mathrm{Cr}^{+2}$ works with insulin to regulate glucose and also lowered free fatty acid levels by $24 \%$, blood urea by $33 \%$ and creatinine level by $25 \%$ and reduced the severity of glomerular sclerosis and confirmed by normal renal tubular appearance in a rat model of type 2 diabetes mellitus group treated with chromium (Sahin et al., 2007). The effect of trace elements on body weight noted in this study was suggested that chromium is important in the burning of carbohydrates and fats in the body. Chromium supplement is believed to reduce food cravings and appetite, thereby assisting weight loss (Lukaski et al., 2007). But these obtained results may be due to chromium helps maintained the efficiency of C-peptide and insulin, which then helps maintain the blood glucose level. These nutritional supplements permit the transmission of glucose to muscle cells instead of fat cells. Chromium supplement increases protein synthesis. Thus, it is beneficial in building muscles. Moreover, Chromium supplementation has at best modest effects on body weight or composition in individuals with diabetes (Hallmark et al., 1996). 
Our data agree with Tobia et al (1998) who found that administration of zinc to streptozotocininduced diabetic rats was able to restore normoglycemia by enhancing glucose oxidation and stimulating glucose uptake by tissues. Zinc similarly exerts insulin-suppressive action by attenuating the hypersecretion of insulin associated with the prediabetic pancreas, thus "rest-"beta cells and preserving their structure and function (Shisheva et al., 1994).
In conclusion, the present study demonstrates the antiglycemic, antioxidant effects of trace elements $\left(\mathrm{Se}^{+2}, \mathrm{Cr}^{+2}\right.$ and $\left.\mathrm{Zn}^{+2}\right)$ in comparison with glibenclamide antidiabetic drug. The present data reveal that trace elements-treatment to STZdiabetic rats produce a remarkable amelioration of body weight, plasma glucose, C-peptide and trace elements. Thus, the safely promising therapeutic dose used in the current study, can be effective in treatment and enhanced levels of plasma trace elements may used as candidate antidiabetic drugs.

Table 1: Statistical analysis (Mean, SD) of body weights of rats in different groups at $4^{\text {nd }}$ and $8^{\text {th }}$ week.

\begin{tabular}{|c|c|c|c|}
\hline \multirow{2}{*}{$\begin{array}{l}\text { Main } \\
\text { Groups }\end{array}$} & \multirow{2}{*}{ Groups } & \multicolumn{2}{|l|}{ Groups } \\
\hline & & $4^{\text {st }}$ week & $8^{\text {th }}$ week \\
\hline \multirow{4}{*}{$\begin{array}{l}\text { I- } \\
\text { Main Health } \\
\text { Group }\end{array}$} & 1)-Ve Control & $149.16 \pm 4.81^{\mathrm{aA}}$ & $153.66 \pm 4.04^{\mathrm{abA}}$ \\
\hline & 2)- $\mathrm{CrCl}_{3}$ & $148.83 \pm 1.64^{\mathrm{aA}}$ & $150.83 \pm 1.05^{\mathrm{abA}}$ \\
\hline & 3)- $\mathrm{Na}_{2} \mathrm{Se}$ & $147.66 \pm 4.90^{\mathrm{aA}}$ & $159.83 \pm 4.46^{\mathrm{aA}}$ \\
\hline & 4)- $\mathrm{ZnSO}_{4}$ & $149.00 \pm 1.39^{\mathrm{aA}}$ & $157.00 \pm 4.27^{\mathrm{aA}}$ \\
\hline \multirow{5}{*}{$\begin{array}{l}\text { II- Main } \\
\text { Diabetic } \\
\text { Group }\end{array}$} & 5) + Ve Diabetic & $123.83 \pm 3.18^{\mathrm{cA}}$ & $111.50 \pm 4.70^{\mathrm{cA}}$ \\
\hline & 6) Glibenclamide & $133.16 \pm 3.74^{\mathrm{bcA}}$ & $145.16 \pm 3.26^{\mathrm{abA}}$ \\
\hline & 7)- $\mathrm{CrCl}_{3}$ & $141.66 \pm 19.29^{\mathrm{abA}}$ & $140.16 \pm 10.66^{\mathrm{bA}}$ \\
\hline & 8)- $\mathrm{Na}_{2} \mathrm{Se}$ & $132.33 \pm 15.29^{\mathrm{bcA}}$ & $145.43 \pm 4.64^{\mathrm{abA}}$ \\
\hline & 9)- $\mathrm{ZnSO}_{4}$ & $135.83 \pm 15.84^{\mathrm{abcA}}$ & $156.50 \pm 12.64^{\mathrm{abB}}$ \\
\hline
\end{tabular}

Data shown are mean \pm standard deviation of number of observations within each treatment.

Data followed by the same letter are not significantly different at $P \leq \mathbf{0 . 0 5}$. Small letters are used for comparison between the means within the column. Capital letters are used to compare means within the row.

Table 2: Effect of trace elements treatments on plasma glucose level in diabetic and non-diabetic rats at $4^{\text {th }}$ and $8^{\text {th }}$ week.

\begin{tabular}{|c|c|c|c|}
\hline \multirow{2}{*}{ Main Groups } & \multirow{2}{*}{ Groups } & \multicolumn{2}{|l|}{ Weeks } \\
\hline & & $4^{\text {st }}$ week & $8^{\text {th }}$ week \\
\hline \multirow{4}{*}{ I- Main Health Group } & 1)-Ve Control & $105.50 \pm 1.48^{\mathrm{eA}}$ & $98.50 \pm 3.84^{\mathrm{dA}}$ \\
\hline & 2)- $\mathrm{CrCl}_{3}$ & $107.00 \pm .2 .94^{\mathrm{eA}}$ & $94.83 \pm 2.12^{\mathrm{dA}}$ \\
\hline & 3)- $\mathrm{Na}_{2} \mathrm{Se}$ & $102.00 \pm 4.65^{\mathrm{eA}}$ & $104.41 \pm 1.56^{\mathrm{cdA}}$ \\
\hline & 4)- $\mathrm{ZnSO}_{4}$ & $96.66 \pm 3.11^{\mathrm{Ea}}$ & $103.00 \pm 1.15^{\mathrm{cdA}}$ \\
\hline \multirow{5}{*}{$\begin{array}{l}\text { II- Main } \\
\text { Diabetic Group }\end{array}$} & 5) + Ve Diabetic & $365.50 \pm 7.66^{\mathrm{aA}}$ & $362.33 \pm 15.22^{\mathrm{aA}}$ \\
\hline & 6) Glibenclamide & $155.00 \pm .6 .77^{\mathrm{dA}}$ & $123.33 \pm 1.94^{\mathrm{bB}}$ \\
\hline & 7)- $\mathrm{CrCl}_{3}$ & $188.83 \pm 38.59^{\mathrm{bcA}}$ & $112.50 \pm 4.07^{\mathrm{bcB}}$ \\
\hline & 8)- $\mathrm{Na}_{2} \mathrm{Se}$ & $179.83 \pm 46.64^{\mathrm{cA}}$ & $118.16 \pm 5.53^{\mathrm{bcB}}$ \\
\hline & 9)- $\mathrm{ZnSO}_{4}$ & $198.33 \pm 28.72^{\mathrm{bA}}$ & $125.00 \pm 5.34^{\mathrm{bB}}$ \\
\hline
\end{tabular}

Data shown are mean \pm standard deviation of number of observations within each treatment.

Data followed by the same letter are not significantly different at $\mathbf{P} \leq \mathbf{0 . 0 5}$. Small letters are used for comparison between the means within the column. Capital letters are used to compare means within the row. 
Table (3):- effect of trace elements treatments on plasma C-peptide in diabetic and non diabetic rats at $4^{\text {th }}$ and $8^{\text {th }}$ week

\begin{tabular}{|c|c|c|c|}
\hline \multirow{2}{*}{ Main Groups } & \multirow{2}{*}{ Groups } & \multicolumn{2}{|c|}{ Weeks } \\
\hline & & $4^{\text {st }}$ week & $8^{\text {th }}$ week \\
\hline \multirow{4}{*}{ 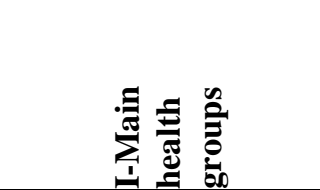 } & 1)-Ve Control & $1.48 \pm 0.02^{\mathrm{bA}}$ & $1.48 \pm 0.01^{\mathrm{aA}}$ \\
\hline & 2)- $\mathrm{CrCl}_{3}$ & $1.53 \pm 0.01^{\mathrm{aA}}$ & $1.4083 \pm 0.01^{\mathrm{bcB}}$ \\
\hline & 3)- $\mathrm{Na}_{2} \mathrm{Se}$ & $1.44 \pm 0.01^{\mathrm{bA}}$ & $1.34 \pm 0.008^{\mathrm{dB}}$ \\
\hline & 4)- $\mathrm{ZnSO}_{4}$ & $1.48 \pm 0.003^{\mathrm{bA}}$ & $1.37 \pm 0.008^{\mathrm{eB}}$ \\
\hline \multirow{5}{*}{$\begin{array}{l}\text { II-- } \\
\text { Main diabetic group }\end{array}$} & 5) + Ve Diabetic & $0.53 \pm 0.006^{\mathrm{fA}}$ & $0.46 \pm 0.02^{\mathrm{eB}}$ \\
\hline & $\begin{array}{c}\text { 6) } \\
\text { Glibenclamide }\end{array}$ & $1.36 \pm 0.006^{\mathrm{cB}}$ & $1.45 \pm 0.01^{\mathrm{abA}}$ \\
\hline & 7)- $\mathrm{CrCl}_{3}$ & $1.21 \pm 0.05^{\mathrm{dB}}$ & $1.47 \pm 0.02^{\mathrm{aA}}$ \\
\hline & 8)- $\mathrm{Na}_{2} \mathrm{Se}$ & $1.09 \pm 0.02^{\mathrm{eB}}$ & $1.44 \pm 0.008^{\mathrm{abA}}$ \\
\hline & 9)- $\mathrm{ZnSO}_{4}$ & $1.13 \pm 0.01^{\mathrm{eB}}$ & $1.45 \pm 0.009^{\mathrm{aA}}$ \\
\hline
\end{tabular}

Data shown are mean \pm standard deviation of number of observations within each treatment.

Data followed by the same letter are not significantly different at $\mathbf{P} \leq \mathbf{0 . 0 5}$. Small letters are used for comparison between the means within the column. Capital letters are used to compare means within the row.

Table (4):- Effect of trace elements treatments on serum chromium $\left(\mathrm{Cr}^{+2}\right)(\mathrm{ng} / \mathrm{ml})$ in diabetic and non diabetic rats at $4^{\text {th }}$ and $8^{\text {th }}$ week.

\begin{tabular}{|c|c|c|c|}
\hline \multirow{2}{*}{ Groups } & \multirow{2}{*}{ Groups } & \multicolumn{2}{|c|}{ Weeks } \\
\hline & & $4^{\text {st }}$ week & $8^{\text {th }}$ week \\
\hline \multirow{4}{*}{$\begin{array}{l}\text { I-Main } \\
\text { groups }\end{array}$} & 1)-Ve Control & $0.75 \pm 0.02^{\mathrm{dB}}$ & $0.90 \pm 0.004^{\mathrm{bA}}$ \\
\hline & 2)- $\mathrm{CrCl}_{3}$ & $0.88 \pm 0.013^{\mathrm{aB}}$ & $0.96 \pm 0.003^{\mathrm{aB}}$ \\
\hline & 3)- $\mathrm{Na}_{2} \mathrm{Se}$ & $0.82 \pm 0.004^{\mathrm{bB}}$ & $0.90 \pm 0.006^{\mathrm{bA}}$ \\
\hline & 4)- $\mathrm{ZnSO}_{4}$ & $0.83 \pm 0.009^{\mathrm{bB}}$ & $0.90 \pm 0.006^{\mathrm{bA}}$ \\
\hline \multirow{5}{*}{$\begin{array}{l}\text { II- Main diabetic } \\
\text { groups }\end{array}$} & 5) + Ve Diabetic & $0.57 \pm 0.04^{\mathrm{fA}}$ & $0.47 \pm 0.006^{\mathrm{dB}}$ \\
\hline & 6) Glibenclamide & $0.75 \pm 0.02^{\mathrm{dB}}$ & $0.88 \pm 0.007^{\mathrm{bA}}$ \\
\hline & 7)- $\mathrm{CrCl}_{3}$ & $0.80 \pm 0.004^{\mathrm{cB}}$ & $0.90 \pm 0.005^{\mathrm{bA}}$ \\
\hline & 8)- $\mathrm{Na}_{2} \mathrm{Se}$ & $0.60 \pm 0.004^{\mathrm{eA}}$ & $0.56 \pm 0.006^{\mathrm{cB}}$ \\
\hline & 9)- $\mathrm{ZnSO}_{4}$ & $0.58 \pm 0.01^{\text {ef } A}$ & $0.47 \pm 0.01^{\mathrm{dB}}$ \\
\hline
\end{tabular}

Data shown are mean \pm standard deviation of animal in each group.

Data followed by the same letter are not significantly different at $\mathbf{P} \leq \mathbf{0 . 0 5}$.

Small letters are used for comparison between the means within the columns.

Capital letters are used to compare means within the rows.

Table (5):-- Effect of trace elements treatments on serum Selenium $\mathrm{Se}^{-2}$ (ng/dl) in diabetic and non diabetic rats at $4^{\text {th }}$ and $8^{\text {th }}$ week.

\begin{tabular}{|c|c|c|c|}
\hline \multirow{2}{*}{ Main Groups } & \multirow{2}{*}{ Groups } & \multicolumn{2}{|c|}{ Weeks } \\
\hline & & $4^{\text {st }}$ week & $8^{\text {th }}$ week \\
\hline \multirow{4}{*}{$\begin{array}{l}\text { I- } \quad \text { Main } \\
\text { health } \\
\text { groups }\end{array}$} & 1)-Ve Control & $2.74 \pm 0.04^{\mathrm{bB}}$ & $2.81 \pm 0.004^{\mathrm{bA}}$ \\
\hline & 2)- $\mathrm{CrCl}_{3}$ & $2.75 \pm 0.04^{\mathrm{bB}}$ & $2.82 \pm 0.002^{\mathrm{bA}}$ \\
\hline & 3)- $\mathrm{Na}_{2} \mathrm{Se}$ & $2.87 \pm 0.008^{\mathrm{aA}}$ & $2.90 \pm 0.005^{\mathrm{aA}}$ \\
\hline & 4)- $\mathrm{ZnSO}_{4}$ & $2.74 \pm 0.32^{\mathrm{bB}}$ & $2.82 \pm 0.004^{\mathrm{bA}}$ \\
\hline \multirow{5}{*}{$\begin{array}{l}\text { II- } \quad \text { Main } \\
\text { diabetic } \\
\text { groups }\end{array}$} & 5) + Ve Diabetic & $1.33 \pm 0.02^{\mathrm{fA}}$ & $0.915 \pm 0.02^{\mathrm{gB}}$ \\
\hline & 6) Glibenclamide & $2.50 \pm 0.06^{\mathrm{cB}}$ & $2.60 \pm 0.009^{\mathrm{dA}}$ \\
\hline & 7)- $\mathrm{CrCl}_{3}$ & $1.38 \pm 002^{\mathrm{eA}}$ & $1.10 \pm 0.01^{\mathrm{fB}}$ \\
\hline & 8)- $\mathrm{Na}_{2} \mathrm{Se}$ & $2.50 \pm 0.007^{\mathrm{cB}}$ & $2.70 \pm 0.01^{\mathrm{cA}}$ \\
\hline & 9)- $\mathrm{ZnSO}_{4}$ & $1.48 \pm 0.02^{\mathrm{dB}}$ & $1.63 \pm 0.02^{\mathrm{eA}}$ \\
\hline
\end{tabular}

Data shown are mean \pm standard deviation of animal in each group.

Data followed by the same letter are not significantly different at $\mathbf{P} \leq \mathbf{0 . 0 5}$.

Small letters are used for comparison between the means within the columns.

Capital letters are used to compare means within the rows. 
Table (6): Effect of trace elements treatments on serum $\mathrm{Zn}^{+2}$ in diabetic and non diabetic rats at $4^{\text {th }}$ and 8 week.

\begin{tabular}{|c|c|c|c|}
\hline \multirow{2}{*}{ Main Groups } & \multirow{2}{*}{ Groups } & \multicolumn{2}{|c|}{ Weeks } \\
\hline & & $4^{\text {st }}$ week & $8^{\text {th }}$ week \\
\hline \multirow{4}{*}{ 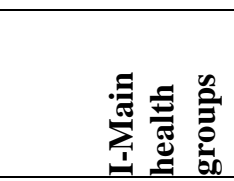 } & 1)-Ve Control & $3.73 \pm 0.03^{\mathrm{cB}}$ & $4.10 \pm 0.005^{\mathrm{bB}}$ \\
\hline & 2)- $\mathrm{CrCl}_{3}$ & $3.85 \pm 0.02^{\mathrm{bB}}$ & $4.11 \pm 0.005^{\mathrm{bA}}$ \\
\hline & 3)- $\mathrm{Na}_{2} \mathrm{Se}$ & $3.82 \pm 0.04^{\mathrm{bB}}$ & $4.30 \pm 0.006^{\mathrm{aA}}$ \\
\hline & 4)- $\mathrm{ZnSO}_{4}$ & $3.96 \pm 0.036^{\mathrm{aB}}$ & $4.35 \pm 0.01^{\mathrm{aA}}$ \\
\hline \multirow{5}{*}{ 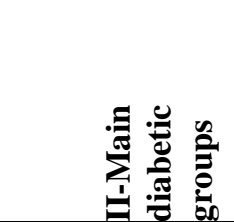 } & 5) + Ve Diabetic & $2.23 \pm 0.03^{\mathrm{eA}}$ & $2.03 \pm 0.03^{\mathrm{eB}}$ \\
\hline & 6) Glibenclamide & $3.43 \pm 0.10^{\mathrm{dB}}$ & $3.89 \pm 0.1^{\mathrm{cA}}$ \\
\hline & 7)- $\mathrm{CrCl}_{3}$ & $1.91 \pm 0.009^{\mathrm{fB}}$ & $2.01 \pm 0.006^{\mathrm{eA}}$ \\
\hline & 8)- $\mathrm{Na}_{2} \mathrm{Se}$ & $2.20 \pm 0.01^{\mathrm{eB}}$ & $2.41 \pm 0.01^{\mathrm{dA}}$ \\
\hline & 9)- $\mathrm{ZnSO}_{4}$ & $3.38 \pm 0.55^{\mathrm{dB}}$ & $4.09 \pm 0.01^{\mathrm{bA}}$ \\
\hline
\end{tabular}

Data shown are mean \pm standard deviation of animal in each group.

Data followed by the same letter are not significantly different at $P \leq 0.05$.

Small letters are used for comparison between the means within the columns.

Capital letters are used to compare means within the rows.

\section{References}

Abel ED, Peroni O, Kim JK, Kim YB, Boss O, Hadro E, Minnemann T, Shulman GI, Kahn BB (2001). Adipose selective targeting of the GLUT4 gene impairs insulin action in muscle and liver. Nature 409, 729-733.

Alderson NL, Chachich ME, Frizzell N, Canning P, Metz TO, Januszewski AS. (2004). Effect of antioxidants and ACE inhibition on chemical modification of proteins and progression of nephropathy in streptozotocin diabetic rat. Diabetologia. 47: 1385-1395.

Allain CC, Poon LS, Chan CS, Richmond W, Fu PC. (1974). Enzymatic determination of total serum cholesterol. Clin Chem 20: 470 .

Al-Shamaony L, Al-Khazraji SM, Twaiji HA. (1994). Hypoglycemic effect of Artemisia herba alba II. Effect of a valuable extract on some blood parameters in diabetic animals. $\mathbf{J}$ Ethnopharmacol; 43: 167.

Aly HF, Mantawy MM. (2012). Therapeutical Chemistry Department, National Research Center, Giza (Egypt) European Review for Medical and Pharmacological Science, 16: 66-78.

Andallu B, Varadacharyulu N. (2003). Antioxidant role of mulberry leaves in streptozotocin-diabetic rats. Clin Chim Acta; 338: 3-10.

Andrade-Cetto A, Wiedenfeld H, Revilla Mac, Islay S. (2000). Hypoglycemic effect of Equisetum myriochaitum aerial parts on streptozotocin diabetic rats. J Ethnopharmacol; 72: 129137.

Battell ML, Delgetty HLM, Mcneil JH. (1998). Sodium selenate corrects glucose tolerance and heart function in STZ diabetic rat. Mol Cell Biochem. 179: 27-34.

Baynes JW.(1991) Role of oxidative stress in development of complications in diabetes. Diabetes; 40:405-411.

Belek DD, Betuing S, Tuttle MJ, Graveleau C, Young ME, Pham M, Zhang D, Cooksey RC, Mcclain DA, Litwin SE, Taegtmeyer H, Severson D, Kahn CR, Abel ED. (2002). Insulin signaling coordinately regulates cardiac size, metabolism, and contractile protein isoform expression. J Clin Invest. 109: 629-639.

Bonger A, Garcia-Webb P.(1984). C-Peptide Measurement: Methods and Clinical Utility. CRC Critical Reviews in Clinical Laboratory Sciences. 19:297-306

Chanarin I (1989). Textbook of laboratory haematology: An account of laboratory techniques. Churchill living stone.new York,pp.107

Chen V, Ianuzzo CD (1982). Dosage effect of streptozotocin on rat tissue enzyme activities and glycogen concentration. Can J Physiol Pharmacol; 60: 1251-1264.
Fossati P, Prencipe L. (1982) Serum Triglycerides Determined Colorimetrically with an Enzyme that Produces Hydrogen Peroxide. Clinical Chemistry, 28, 2077-2080.

Friedwald WT, Levy RI, Fredrickson DS. (1972). Estimation of the concentration of LDL-C in plasma without use of the preparative ultracentrifuge. Clin Chem. 18:449-502.

Garg MC, Ojha S, Bansal D. (1996). Antioxidant Status of streptozotocin - diabetic rats. Indian J Exp Biol; 34: 264-271.

Hallmark MA, Reynolds TH, DeSouza CA, Dotson CO, Anderson RA, Rogers MA. (1996). Effects of chromium and resistive training on muscle strength and body composition. Med. Sci. Sports Exerc., 28: 139-144.

Horie S, Agai H, Yuuki T, Hanada S, Nakamura N. (1998). Effectiveness of recombinant human serum albumin in the treatment of ascites in liver cirrhosis: evidence from animal model. Gen Pharmacol. 31: 811-815.

Hussein AA, Hussein MA, Soha AH, Anwar K. (2014). Antidiabetic Activity of Viciafaba L. vicine and its Odeglycosylation product, divicinein STZ-induced diabetic rats. International Journal of Pharma Sciences. 2: 454-463

Hussein MA. (2010). Purslane extract effects on obesityinduced diabetic rats fed a high-fat diet. MJN, 3: 219-229.

Jacob RA. (1995). The integrated antioxidant system. Nutr Res; 15: 755-762.

Jain SK, Kannan K. (2001). Chromium Chloride Inhibits Oxidative Stress and TNF- $\alpha$ Secretion Caused by Exposure to High Glucose in Cultured U937 Monocytes. Biochemical and Biophysical Research Communications 289: 687-691.

Ju JB, JiSK, Choi CW, Lee HK, Oh T, Kim C. (2008). Comparison between ethanolic and aqueous extracts from Chinese juniper berries for hypoglycaemic and hypolipidemic effects in alloxaninduced diabetic rats. J. Ethnopharmacol. 115:110-115.

Kochhar A, Malkit N, Rajbir S. (2007). Effect of supplementation of traditional medicinal plants on serum lipid profile in non-insulin dependent diabetics. J. Hum. Ecol, 5: 13540 .

Kowluru RA, Engerman RL, Case GL, Kern TS. (2001). Retinal glutamate in diabetes and effect of antioxidants. Neurochem Int, 38: 385-390.

Kraegen EW, Sowden JA, Halstead MB, Clark PW, Rodnick KJ, Chisholw DJ, James DE. (1994). Glucose transporters and in vivo glucose uptake in skeletal and cardiac muscle: fasting, insulin cells. Bioessays. 16: 753-759.

Kunwar A, Priyadarsini KI. (2011). Free radicals, oxidative stress and importance of antioxidants in human health. J Med Allied Sci, 1(2): 53-60. 
Liu H, Liu X, Lee J, Liu Y, Yang H, Wang G (2008). Insulin therapy restores impaired function and expression of Pglycoprotein in blood-brain barrier of experimental diabetes. Biochem Pharmacol. 75(8):1649-1658).

Lukaski HC, Siders WA, Penland JG (2007). Chromium picolinate supplementation in women: effects on body weight, composition and iron status. Nutrition, 23: 187-195.

Marklund S, Marklund G. (1974). Involvement of the superoxide anion radical in the autoxidation of pyrogallol and a convenient assay for superoxide dismutase. Eur J Biochem. 16; 47(3):469-74.

Mendez D, Jensen R, Mcelroy L, Pena J, Esquerra R. (2005). The effect of non-enzymatic glycation on the unfolding of human serum albumin. Arch Biochem Biophys. 2: 92-99.

Nemati S, Jafary SP, Nahrevanian H, Farahmand M, Nahrevanian S. (2012). Immuno-biochemical alterations in Leishmania major infected balb/ $\mathrm{c}$ mice after immunization with killed Leishmania vaccine and BCG as adjuvant. Curr Res J Biol Sci, 4(6): 706-712.

O'Connell BS. (2001). Select vitamins and minerals in the management of diabetes. Diabetes Spectrum.14:133-148.

Obrosova IG, Minchenko AG, Marinescu V, Fathallah L, Kennedy A, Stockert CM, Frank RN, Stevens MJ. (2001). Antioxidants attenuate early up regulation of retinal vascular endothelial growth factor in streptozotocin-diabetic rats. Diabetologia. 44:1102-1110.

Olson SE, Seidel GE, Jr. (2000) Culture of in vitro-produced bovine embryos with vitamin $\mathrm{E}$ improves development in vitro and after transfer to recipients. Biol Reprod. 62(2): 248-52.

Ozturia Y, Altan VM, Yildizoglu A. (1996). Effect of experimental diabetes and insulin on smooth muscle functions. Pharma Revi; 48: 69-75.

Qiao W, Peng Z, Wang Z, Wei J, Zhou A.(2009). Biol Trace Elem Res.,131(2):133-42.

Rajasekaran S, Sivagnanam K, Ravi K, Subramanian S (2004) Hypoglycemic effect of Aloe vera gel on streptozotocininduced diabetic rats. J Med Food; 7: 61-68. Ramachandran S, Rajasekaran A, Kumar K. (2011). Antidiabetic, antihyperlipidemic and antioxidant potential of methanol extract of Tectonagrandis flowers in streptozotocin induced diabetic rats. Asian Pac J Trop Med, 4: 624- 631.

Sahin K, Onderci M, Tuzcu M, Ustundag B, Cikim G, Ozercan I, Sriramoju I, Juturu V, Komorowski J (2007). Effect of chromium on carbohydrate and lipid metabolism in a rat model of type 2 diabetes mellitus: the fat-fed, streptozotocin treated rat. Metabolism, 56(9): 1233-40.

Singh SK, Achyut NK, Gupta RK, Dolly J, Watal G. (2007). Assessment of antidiabetic potential of Cynodondactyl on extract in STZ-diabetic rats. J. Ethnopharmacol. 114:174-179. Sivajothi V, Akalanka D, Balasundaram J Balasubramanian R. (2008). Antihyperglycemica ntihyperlipidemic and antioxidant effect of Phyllanthusrheediion streptozotocin induced diabetic rats. Iran J. Pharm. Res, 1:53-59.

Tian-Jiao Xu, Liu Y, Yuan B. (2011). Effect of insulin in combination with selenium on IRS/PI3K-mediated GLUT4 expression in cardiac muscle of diabetic rats. European Review for Medical and Pharmacological Sciences. 15: 1452-1460.

Tobia MH, Zdanowicz M, Wingertzahn MA, Atkinson BM, Slonim AE, Raul A, Wapnir RA. (1998). The role of dietary zinc in modifying the onset and severity of spontaneous diabetes in the BB Wistar rat. Mol Gen Metab. 63: 205-213. Shisheva A, Gefel D, Shechter Y. (1994). Insulin-like effects of zinc ion in vitro and in vivo. Diabetes. 41; 982-988.
Tomlinson KC, Gardiner SM, Hebden RA, Bennett T. (1992). Functional consequences of streptozotocin-induced diabetes mellitus, with particular reference to the cardiovascular system. Pharmacol Rev; 44: 103-110.

Toyoda T, An D, Witczak CA, Koh HJ, Hirshman MF, Fujii N, Goodyear LJ. (2010). Myolc regulates glucose uptake in mouse skeletal muscle. J Biol Chem, 12: 1-17. Trinder P. (1969) Glucose determination method (enzymatic colorimetric method). Ann Clin Biochem; 6: 24-31.

Trivedi N.A., Majumder B., Bhatt J.D Hemavathi K.G. Effects of Shilajit on blood glucose and lipid profiles in alloxaninduced diabetic rats. Indian J Pharmacol. 2004; 36: 373-376. Uchiyama M, Mihara M. (1978). Determination of malondialdehyde precursor in tissues by thiobarbituric acid test. Anal. Biochem., 86: $271-278$

Warnick GR, Nguyen T, Alberts AA. (1985). Comparison of improved precipitation methods for quantification of highdensity lipoprotein cholesterol. Clin Chem. 31:217.

Yanardag R, Peksel A, Yesilyaprak B, Doger MM, Atac AI. (2005): Effects of a combination of niacin and chromium (III)chloride on the skin and lungs of hyperlipemic rats. 103 (3): 249-260

Zhongli Peng (2010). Biological Trace Element Research 137, 2: 226-234

Zine K, EL-Hadjla D, Naima L (2007). The beneficial effect of vitamin E supplementation on zinc status, carbohydrate metabolism, transaminases and alkaline phosphatase activities in alloxan-diabetic rats fed on zinc deficiency diet. Int J Diabetes \& Metabolism, 15: 46-50.

Tawfeq A, Adnan J, AL-Rehailyb, Joanna R, Polsc, John R, Porter, Jaber S, Mossab, Bahar Ahmed. Three new diterpenes and the biological activity of different extracts of Jasonia Montana. Natural Product Research. 2005;19:253-65.

Tomonori N, Tadashi H, Ichiro T. A Green Tea Extract High in Catechins Reduces Body Fat and Cardiovascular Risks in Humans. Obesity. 2007;6:1473-83.

Valko M, Leibfritz D, Moncol J, Cronin MT, Mazur M, Telser J: Free radicals and antioxidants in normal physiological functions and human disease. Int J Biochem Cell Biol 2007, 39(1):44-84

van Acker SABE, Bast A, van der Vijgh, WJF. In: Flavonoids in Health and Disease; Rice-Evans, C.A.; Packer, L., Eds.; Marcel Dekker: New York, 1998, pp. 221-251.

van Acker SABE,van den Berg, DJ, Tromp MNJL, Griffioen DH, van Bennekom WP, van der Vijgh WJF, Bast A. A partial least squares regression study with antioxidant flavonoid compounds. Free Radic. Biol. Med., 1996, 20: 331342.

Weber ML, Weigand MA, Giaisi M, Suss D, Treiber MK, Baumann S, Ritsou E, Breitkretz R, Krammer PH: Vitamin $\mathrm{E}$ inhibits CD95 ligand expression and protects $\mathrm{T}$ cell from activation-induced cell death. J Clin Invest 2002, 110:681-690. Whitton PS: Inflammation as a causative factor in the aetiology of Parkinson's disease. Br J Pharmacol 2007, 150(8):963-976. Williams RJ, Spencer JPE, Rice-Evans C. Free Radical Biology \& Medicine. Free Radic. Biol. Med., 2004, 36: 838-849.

Zhao B, Li X, He R, Cheng S, Xin W. Scavenging effect of extracts of green tea and natural antioxidants on active oxygen radicals. Cell Biophys. 1989;14:175-85. 